\title{
PKM PENDAMPINGAN PENGEMBANGAN ALAT PERAGA MEKANIKA APLIKATIF BAGI GURU IPA
}

\author{
Islahudin ${ }^{1)}$, Saiful Prayogi2), \& Haifaturrahmah"3) \\ 1) Prodi Pendidikan Fisika, FKIP, Universitas Muhammadiyah Mataram, Mataram, NTB, Indonesia \\ 2) Prodi Pendidikan Fisika, FSTT, Universitas Pendidikan Mandalika, Mataram, NTB, Indonesia \\ ${ }^{3)}$ Prodi Pendidikan Guru Sekolah Dasar, FKIP, Universitas Muhammadiyah Mataram, Mataram, NTB, Indonesia \\ Corresponding author: islahudin.ntb@gmail.com
}

Diterima 14 Oktober 2020, Direvisi 17 November 2020, Disetujui 17 November 2020

\begin{abstract}
ABSTRAK
Kegiatan pengabdian kepada masyarakat (PKM) ini bertujuan melaksanakan pendampingan pengembangan alat peraga mekanik aplikatif bagi guru IPA. Sebagai pendukung alat peraga yang dikembangkan, dalam kegiatan PKM ini juga dilakukan pendampingan pengembangan lembar kerja peserta didik (LKPD) berbasis keterampilan proses sains. Mitra kegiatan PKM, yaitu Madrasah Aliyah NW Sepit, Kecamatan Keruak, Kabupaten Lombok Timur, dan anggota kelompok guru mitra yang terlibat sebanyak 12 guru IPA pada rumpun mata pelajaran fisika, biologi, dan kimia. Metode pelaksanaan PKM melalui kegiatan pelatihan dan pendampingan yang dirinci menjadi empat tahap, mulai dari persiapan, pelatihan dan pendampingan, konsultasi dan presentasi produk hasil pendampingan, sampai dengan implementasi produk hasil pendampingan ke peserta didik pada pembelajaran IPA. Hasil kegiatan PKM secara umum, yaitu guru IPA sebagai kelompok mitra telah memiliki kompetensi dalam mengembangkan alat peraga mekanik aplikatif dan LKPD berbasis keterampilan proses sains sebagai pendukung implementasi alat peraga ke peserta didik. Produk alat peraga aplikatif yang dikembangkan guru menjadi fondasi pembelajaran inovatif guru IPA dalam menciptakan proses pembelajaran yang atraktif dan menarik untuk mencapai hasil belajar yang lebih optimal. Hasil kegiatan PKM ini dapat menjadi referensi pelaksanaan kegiatan PKM serupa untuk dapat dilaksanakan pada kelompok guru IPA di kabupaten lain sebagai kegiatan suplemen bagi guru dalam meningkatkan kualitas proses pembelajaran IPA di kelas.
\end{abstract}

Kata kunci: Alat peraga; kelompok guru IPA; lembar kerja peserta didik; mekanika aplikatif.

\begin{abstract}
This community service (PKM) activity aims to assist in the development of applicative mechanical props for science teachers. As a support for the props that were developed, in this activity there was also assistance in the development of student worksheets (LKPD) based on science process skills. PKM activity partners, namely Madrasah Aliyah NW Sepit, kecamatan Keruak, kabupaten Lombok Timur, and members of the group of partner teachers involved were 12 science teachers in a group of physics, biology, and chemistry subjects. The methods of implementing PKM through training and mentoring activities are carried out in four stages, starting from preparation, training and assistance, consultation and presentation of mentored products, to implementation of mentoring products to students in science learning. The result of PKM activities is that science teachers as a partner group have been competent in developing applicative mechanical props and LKPD based on science process skills as a support for the implementation of props to the students. The applicative props product developed by the teacher becomes the foundation of innovative learning of science teachers in creating attractive learning processes to achieve optimal learning outcomes. The results of these PKM activities can be a reference for the implementation of similar PKM activities to be carried out in groups of science teachers in other districts as a supplementary activity for teachers in improving the quality of the science learning process in the classroom.
\end{abstract}

Keywords: Applicative mechanical props; student worksheets; science teachers group

\section{PENDAHULUAN}

Diakui secara universal bahwa guru sebagai tulang punggung dari sistem pendidikan karena pengetahuan ditransfer dari guru (Malik, M. A., Murtaza, A. \& Khan, 2011). Setiap negara sangat mementingkan kualitas guru dan kebijakan pendidikan salah satunya dipengaruhi oleh adanya kesadaran bahwa guru memiliki peran kunci untuk dimainkan dalam menentukan kualitas output institusi pendidikan, 
dan adanya pendidikan karena keberadaan dari seorang guru (Esmaeili et al., 2015). Salah satu kunci pendidikan yang berkualitas terletak pada kualitas guru, secara artistik bahwa kualitas siswa tergantung pada kualitas guru (Chochran, 2006). Pentingnya peran guru untuk meningkatkan kualitas pembelajaran menjadi isu sentral dan menjadi permasalahan yang selalu masuk ranah kebijakan, karena jika terjadi penurunan kualitas pendidikan, kesalahan tersebut cenderung dialamatkan kepada guru (Xhemajli, 2016), hal ini karena guru menjadi determinant factor dalam meningkatkan mutu pendidikan secara umum dan kualitas pembelajaran secara khusus baik dalam arti proses maupun hasil.

Peningkatan kualitas penyelenggaraan pendidikan ditandai dengan adanya reformasi kurikulum. Di Indonesia, pemerintah telah menetapkan beberapa kebijakan untuk meningkatkan kualitas pendidikan dan pembelajaran, salah satunya dengan menetapkan penerapan kurikulum 2013 (K-13) pada semua jenjang pendidikan dasar dan menengah. Esensi dari K-13 adalah pengembangan kreativitas dan kemampuan berpikir peserta didik dengan pendekatan pembelajaran saintifik. Penerapan K-13 menuntut peran guru untuk dapat berinovasi dalam pembelajaran untuk mencapai tujuan yang diharapkan. Tingkat pencapaian tujuan pembelajaran terkait dengan tingkat kemampuan guru di dalam berinovasi yang memberi peluang peserta didik untuk mengembangkan keterampilan melalui latihan di kelas (Khalkhali, 2010). Indikatornya, yaitu kualitas interaksi antara guru dan peserta didik, aktivitas berdasarkan tujuan yang telah ditentukan, desain pembelajaran yang terorganisir, dan mengembangkan fasilitas proses pembelajaran (Zahed, 2012).

Melihat pentingnya peran guru dalam berinovasi dalam pembelajaran, tim pengabdian kepada masyarakat (PKM) Universitas Muhammadiyah Mataram telah melakukan survey dan wawancara (in-dept interview) kepada guru IPA di Madrasah Aliyah NW Sepit yang merupakan salah satu sekolah swasta di kecamatan Keruak, kabupaten Lombok Timur. Wawancara terkait dengan proses pembelajaran yang dilakukan, inovasi guru dalam pembelajaran, penggunaan media dan alat peraga pembelajaran. Hasil wawancara menunjukkan beberapa permasalahan terkait pembelajaran IPA, antara lain guru kesulitan dalam berinovasi mengembangkan pembelajaran IPA karena sekolah tidak memiliki laboratorium dan sarana pendukung pembelajaran IPA yang memadai, dan selama ini belum ada upaya dari guru mengembangkan alat peraga IPA dikarenakan dukungan sekolah masih minim. Selain itu, selama ini guru menyusun lembar kerja peserta didik (LKPD) hanya berisi latihan soal untuk dikerjakan peserta didik, padahal sejatinya LKPD merupakan panduan bagi peserta didik dalam melaksanakan kegiatan pembelajaran berbasis pada kegiatan eksperimen/praktikum. Permasalahan ini berdampak pada proses pembelajaran yang mengandalkan metode ceramah dan tanyajawab, dan kurang menekankan pendekatan saintifik sesuai dengan pendekatan yang ditekankan dalam K13.

Kondisi seperti yang telah diuraikan di atas menarik perhatian tim PKM untuk melaksanakan pengabdian di sekolah pada guru-guru yang tergabung dalam guru IPA. Meninjau permasalahan prioritas yang dihadapi guru IPA, tim PKM berinisiatif melaksanakan kegiatan pengabdian kepada masyarakat melalui program kemitraan masyarakat tahun 2020 dengan tema PKM Pendampingan Pengembangan Alat Peraga Mekanika Aplikatif Bagi Guru IPA. Mitra kegiatan PKM, yaitu Madrasah Aliyah NW Sepit, Kecamatan Keruak, Kabupaten Lombok Timur. Sekolah mitra tersebut merupakan sekolah yang terletak di kawasan KPPN (Kawasan Perdesaan Prioritas Nasional) karena diperkirakan dari segi potensi dan kemajuan pertumbuhannya bisa menjadi kota-kota baru. Adapun anggota kelompok guru yang terlibat dari sekolah mitra tersebut adalah kelompok guru IPA pada rumpun mata pelajaran fisika, biologi, dan kimia.

\section{METODE}

Metode pelaksanaan PKM melalui kegiatan pelatihan dan pendampingan yang dirinci menjadi empat tahap, yaitu: a) persiapan, b) pelatihan dan pendampingan, c) konsultasi dan presentasi produk hasil pendampingan, dan d) implementasi produk hasil pendampingan ke peserta didik pada pembelajaran IPA, ) evaluasi pelaksaan PKM, dalam hal evaluasi kegiatan PKM indikator keberhasilan dalam pendampingan yaitu pembelajaran inovatif guru IPA; merancang alat peraga IPA; merancang LKPD Berbasis keterampilan Proses Sains (KPS); menerapkan alat peraga dalam pembelajaran di kelas; dan menerapkan LKPD Berbasis KPS dalam pembelajaran. Tim pelaksana PKM terdiri dari tiga orang dosen dan dibantu oleh dua orang mahasiswa, serta kelompok mitra sebanyak 12 orang guru yang tergabung dalam rumpun ilmu IPA (fisika, kimia, dan biologi) terlibat dalam kegiatan PKM. Gambaran ipteks yang ditransfer kepada mitra yang menunjukkan alur kegiatan secara utuh disajikan pada Gambar 1. 


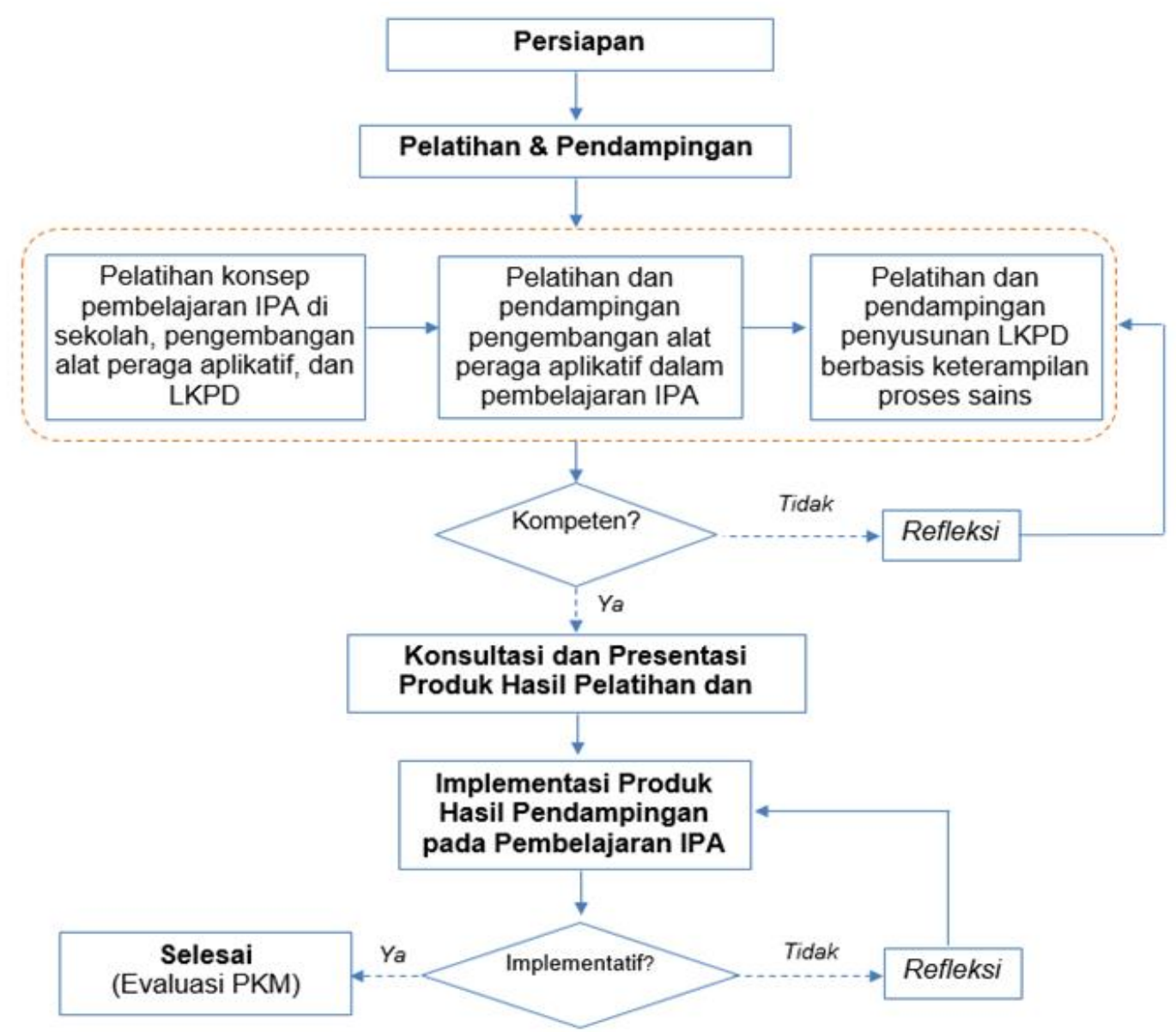

Gambar 1. Alur pelaksanaan kegiatan PKM

Penyampaian materi pelatihan dengan prinsip andragogis mengedepankan diskusi dan tanya jawab. Pada tahap proses pelatihan dan pendampingan, tim PKM melakukan refleksi apakah kelompok mitra kompeten terkait dengan materi pelatihan dan pendampingan. Jika kompeten maka dilanjutkan ke tahap berikutnya, dan jika tidak maka dilakukan refleksi dan tim PKM membuka ruang terlaksananya diskusi dan tanya jawab. Demikian juga pada tahap implementasi di sekolah, di mana ketika proses implementasi ditemukan hambatan dan kendala dalam melatihkan keterampilan proses sains kepada peserta didik maka perlu dilakukan refleksi dilakukan langkah-langkah perbaikan, namun jika tidak ada kendala maka kegiatan selesai dan dilakukan evaluasi kegiatan secara menyeluruh sebagai bahan perbaikan kegiatan PKM di masa-masa mendatang.

Kegiatan PKM dilaksanakan secara kolaboratif bersama dengan mitra, artinya mitra berpartisipasi aktif selama proses pelaksanaan PKM. Bentuk partisipasi mitra, antara lain; a) kelompok mitra siap mengikuti program PKM secara penuh dari awal sampai akhir kegiatan, b) sekolah mitra menyediakan tempat pelatihan dan melakukan mobilisasi peserta agar aktif selama proses pelatihan dan pendampingan, dan c) mitra bersedia membantu dalam menyediakan beberpa bahan dan alat-alat yang diperlukan kelompok mitra dalam mengembangkan alat peraga.

\section{HASIL DAN PEMBAHASAN}

Pada tahap persiapan tim PKM menyusun kerangka acuan kerja (KAK), mengurus surat izin pelaksanaan kegiatan PKM di Dikpora Kabupaten Lombok Timur, komunikasi dengan mitra terkait jumlah peserta PKM dari guru yang akan terlibat, penentuan lokasi pelaksanaan kegiatan PKM, penyamaan persepsi tim PKM dengan kelompok mitra, dan terakhir penyiapan materi pelatihan dan pendampingan di internal tim PKM.

Tahap kedua, yaitu pelatihan dan pendampingan pada kelompok mitra. Konten materi yang disampaikan pada tahap ini, yaitu a) pelatihan konsep pembelajaran IPA di sekolah, pengembangan alat peraga aplikatif, dan lembar kerja peserta didik (LKPD), b) pelatihan dan pendampingan pengembangan 
alat peraga aplikatif dalam pembelajaran IPA, dan c) pelatihan dan pendampingan penyusunan LKPD berbasis keterampilan proses sains sebagaimana pada Gambar 2.

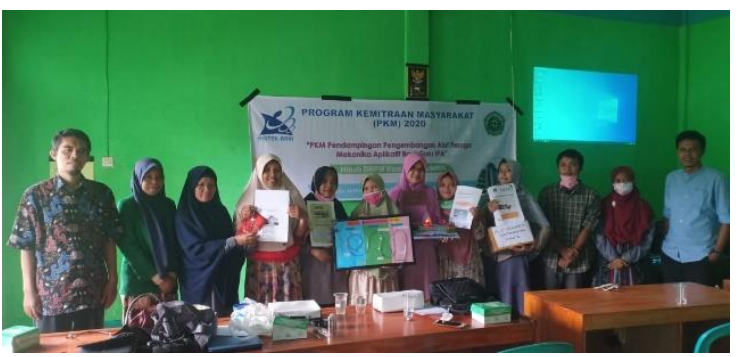

Gambar 2. Pelatihan dan pendampingan pembuatan alat peraga bagi guru IPA

Pada tahap ini, tim PKM dibantu dua mahasiswa memberikan pelatihan dan pendampingan kelompok mitra dalam merancang alat peraga IPA. Salah satu contoh alat peraga IPA yang dirancang seperti pada Gambar 3. Hasil kegiatan PKM pada tahap pelatihan, yaitu para guru kelompok mitra telah memahami konsep pembelajaran IPA di sekolah, konsep pengembangan alat peraga aplikatif, dan konsep penyusunan LKPD. Pada tahap pendampingan, para guru kelompok mitra mampu mengembangkan alat peraga aplikatif dalam pembelajaran IPA dan mampu mengembangkan LKPD berbasis keterampilan proses sains.

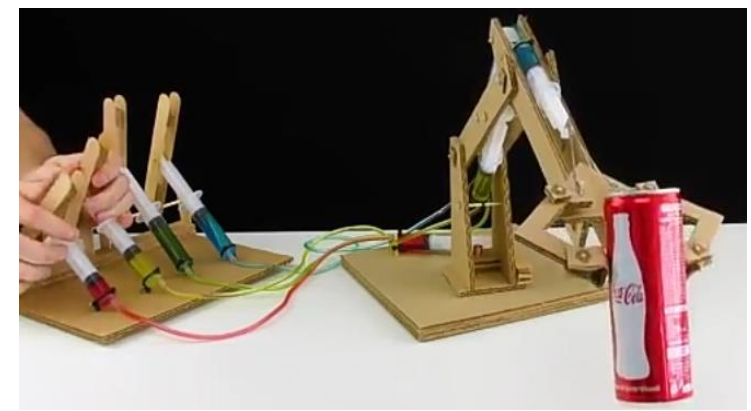

Gambar 3. Alat peraga IPA (hukum Pascal lengan robot)

Tahap ketiga, yaitu konsultasi dan presentasi produk hasil pelatihan dan pendampingan. Produk alat peraga aplikatif yang dikembangkan guru dan LKPD selanjutnya dikonsultasikan dengan tim pelaksana PKM. Konsultasi dimaksudkan untuk mengecek kelayakan produk dan juga kesesuaiannya dengan LKPD yang telah disusun. Setelah konsultasi, selanjutnya alat peraga beserta LKPD yang dikembangkan dipresentasikan tiap guru di depan semua peserta kelompok mitra. Hasil kegiatan pada tahap ini sebanyak empat alat peraga aplikatif dan LKPD dalam pembelajaran IPA dihasilkan kelompok mitra, yaitu alat peraga dan LKPD suhu dan kalor, listrik statis, pembentukan urin, dan larutan elektrolit.

Tahap keempat kegiatan PKM ini, yaitu mengimplementasikan hasil produk alat peraga mekanika aplikatif dan LKPD berbasis KPS yang telah dikembangkan ke dalam proses pembelajaran di kelas. Selama proses pembelajaran masing-masing guru mampu mengukur aspek keterampilan dan hasil belajar peserta didiknya. Hasil pengukuran keterampilan dan hasil belajar dijadikan sebagai umpan balik baik bagi guru maupun sekolah secara umum untuk mengembangkan inovasi-inovasi dalam pembelajaran. Implementasi produk alat peraga aplikatif dan LKPD pada peserta didik di Madrasah Aliyah NW Sepit. Keterlaksanaan pembelajaran menggunakan alat peraga aplikatif dan LKPD diobservasi oleh guru lain kelompok mitra menggunakan lembar observasi keterlaksanaan pembelajaran yang disiapkan tim PKM. Hasil implementasi menunjukkan bahwa guru dapat melaksanakan pembelajaran dengan baik menggunakan alat peraga aplikatif dan LKPD berbasis keterampilan proses sains yang telah mereka kembangkan. Selain itu, pembelajaran juga menjadi menarik dan atraktif dengan adanya simulasi konsep materi yang diajarkan dengan menggunakan alat peraga aplikatif mekanik dalam pembelajaran IPA. Hasil PKM ini menjadi temuan penting bahwa alat peraga aplikatif mekanik yang dikembangkan guru menjadi fondasi inovasiinovasi pembelajaran yang dilaksanakan guru IPA dan menciptakan proses pembelajaran menjadi lebih menarik untuk mencapai hasil belajar yang lebih optimal.

Evaluasi kegiatan PKM dilakukan dan kendala utama dalam pelaksanaan kegiatan PKM ini antara lain, kegiatan dilaksanakan pada masa pandemi Covid-19, sehingga pelaksanaan kegiatan dengan memperhatikan dan menerapkan protokol kesehatan dengan sangat ketat. Namun demikian, kegiatan ini mendapat tanggapan positif dari pihak sekolah mitra dan juga guru IPA sebagai kelompok mitra, harapannya adalah kegiatan serupa dapat terus dilakukan sebagai kegiatan suplemen bagi guru dalam meningkatkan kualitas proses pembelajaran IPA di kelas.

\section{SIMPULAN DAN SARAN}

Kegiatan pengabdian kepada masyarakat (PKM) pendampingan pengembangan alat peraga mekanik aplikatif bagi guru IPA yang melibatkan mitra Madrasah Aliyah NW Sepit telah berjalan dengan baik sesuai dengan perencanaan, di mana guru IPA sebagai kelompok mitra telah memiliki kompetensi dalam mengembangkan alat peraga mekanik 
aplikatif dan LKPD berbasis keterampilan proses sains sebagai pendukung implementasi alat peraga ke peserta didik. Produk alat peraga aplikatif yang dikembangkan guru menjadi fondasi pembelajaran inovatif guru IPA dalam menciptakan proses pembelajaran yang atraktif dan menarik untuk mencapai hasil belajar yang lebih optimal. Disarankan bahwa kegiatan PKM serupa dapat terus dilakukan pada kelompok guru IPA di kabupaten lain sebagai kegiatan suplemen bagi guru dalam meningkatkan kualitas proses pembelajaran IPA di kelas.

\section{UCAPAN TERIMAKASIH}

Tim pelaksana kegiatan PKM mengucapkan terimakasih kepada pihak-pihak yang telah berkontribusi dalam pelaksanaan kegiatan, terutama pihak Madrasah Aliyah NW Sepit yang telah bersedia menjadi mitra dan juga kelompok guru mitra kegiatan PKM ini. Tim PKM berharap kegiatan ini dapat memberi spirit untuk kemajuan pendidikan IPA di Indonesia.

\section{DAFTAR RUJUKAN}

Chochran, M. (2006). Policy, practice and politics in teacher education. Corwin Press.

Esmaeili, Z., Mohamadrezai, H., \& Mohamadrezai, A. (2015). The role of teacher's authority in students' learning. Journal of Education and Practice.

Khalkhali, A. (2010). Presenting a model for edtablishing management of healthy classroom. , 2, 60-71. Journal of Educational Psychology of Islamic Azad University, 2, 60-71.

Malik, M. A., Murtaza, A. \& Khan, A. M. (2011). Role of teachers in managing teaching learning situation. Interdisciplinary Journal of Contemporary Research in Business, 3(5), 783-833.

Xhemajli, A. (2016). The role of the teacher in interactive teaching. International Journal of Cognitive Research in Science, Engineering and Education. https://doi.org/10.5937/IJCRSEE1601031 $X$

Zahed, B. A. (2012). The extent of conformity of teachers verbal and non verbal relaitons within teaching and its association with students educational progress. Journal Os School Psycology, 1(1), 46-61. 